\title{
Online News Media Framing of COVID-19 Pandemic: Probing the Initial Phases of the Disease Outbreak in International Media
}

\author{
Sylvia Ndanu Mutua ${ }^{1}$ (1) Daniel Oloo Ong'ong'a ${ }^{1 *}$ (B)
}

${ }^{1}$ Institute of Communication Studies, Communication University of China, CHINA

*Corresponding Author: oloodaniel2@outlook.com

Citation: Mutua, S. N., \& Ong'ong'a, D. O. (2020). Online News Media Framing of COVID-19 Pandemic: Probing the Initial Phases of the Disease Outbreak in International Media. European Journal of Interactive Multimedia and Education, 1(2), e02006. https://doi.org/10.30935/ejimed/8402

\begin{abstract}
The outbreak of the COVID-19 Pandemic that purpoted to originate in the city of Wuhan draws a lot of questions on the extent of crisis health communication concerning the international media. At the inception stage, in January 2020, it was reported that about ten major cities in China had been affected by this virus at that time labelled as 2019 nCov. By March 10, 2020, the disease had spread to Europe, the UK, Middle-East, and Africa, with more than 114,344 confirmed cases reported globally. In this situation, various scholars have often criticized the media for framing, misinformation, or exaggeration in the news information. In contrast, others have hailed the media for playing an educative and informative role to the public. Utilizing content analysis, framing and consecutive day sampling, this study focused on examining the media coverage of the initial two months of the COVID-19 Pandemic by four international news media organizations namely; BBC, CNN, Al-Jazeera and the People's Daily. The article contributes to the discourse of mass media practice, and application of various research paradigm in deconstructing media framing during critical periods.
\end{abstract}

Keywords: COVID-19, Pandemic, Online news media, misinformation, constructed week, media framing

Received: 8 Jun. 2020 Accepted: 28 Jun. 2020

\section{INTRODUCTION}

January 9, 2020, marked the first fatality case to the coronavirus outbreak that affected the People's Republic of China, with initial reports indicating that the virus to have originated from a seafood market in Wuhan city (Huang et al., 2020). The rapid spread of the disease was further confirmed in other cities in the People's Republic of China with the media at the time reporting a few export cases in Japan, Malaysia, Hong Kong, South Korea, Thailand, Vietnam, Singapore, France, and United States of America (CDC, 2020; WHO, 2020).

According to Huang et al. (2020), the initial response of the local health authorities in the region was the closure of the seafood market on the first day January 2020; at the time, there were 59 patients admitted in hospital with pneumonia-like symptoms sharing an exposure history of their presence at the seafood market. Scientists working on the early stages of the disease confirmed it to be coronavirus with high levels of fatality registered in the first cases (Huang et al., 2020). The disease outbreak showed, some similar characteristics to Middle East Respiratory Syndrome coronavirus (MERS-CoV) and Severe Acute Respiratory Syndrome coronavirus (SARS-CoV) infections. These diseases proved to be fatal, with very high mortality rates (Assiri et al., 2013).
Given that the COVID-19 pandemic was an outbreak at its emergent stage at the moment, local health authorities communicated preventive measures to the public to minimize the infection rates among the population. On the other hand, news media corporations also rushed in to cover the disease outbreak highlighting different aspects of the epidemic. News framing at this stage became an important aspect not only in shaping the public discourse about the outbreak but also in the communication of the disease outbreak management interventions. Additionally, the social, economic, and political factors in the country also provided context for framing the news stories by the international media in choosing which particular aspects to highlight and show emphasis and which ones to exclude. The spread of the disease to other countries offered additional frames and perspectives, especially for news media organizations that are based in countries that had recorded confirmed cases of the disease. This position coincides with Gislason (2013), who posits that the use of particular news frames during a public health emergency has significant effects on the societal understanding and reactions to the outbreak.

Building on previous literature examining the importance of media framing in public health disease outbreaks (Idoiaga-Mondragon et al., 2017; Wallis \& Nerlich, 2005), and drawing on the methodology and theoretical principles of media framing theory, this study analyzed online news stories published between January 1, 2020, and February 29, 2020, by CNN, BBC, Al-Jazeera, and People's Daily. The choice of 
these international media was based on the fact that they are easily recognized as news media brands with global popularity. Also, as reputable news media organizations in their respective regions, an observation also made by Yan and Stewar (2005) in the examination of the media framing of SARS by CNN and BBC. Furthermore, the spread of the virus in different countries, including the United States and France, offers exciting perspectives in drawing comparisons between coverage of the initial stages of disease outbreak in these media houses.

\section{ROLE OF MEDIA IN EPIDEMIC COMMUNICATION}

The media has remained an essential agent in the event of a health epidemic in the 21st century. This was witnessed during the Ebola, SARS, MERS, and now COVID-19 pandemic. Information about infectious diseases that involve unanticipated outbreaks causes severe economic, physical, psychological, and social impact (Ophir, 2018). Communication challenges that come from uncertainty and risk when not properly handled can lead to loss of trust and reputation towards the media while creating an economic crisis and also high mortality rates. During outbreaks, the media's pivotal role not only includes the documentation of the economic impact of the crisis but also creates an avenue for the political and public debate on the handling of the issue (Ophir, 2018).

The perception of people can ameliorate threats and risks when they are provided with the correct public health information. Failure of the media to disseminate this information causes uncertainty and panic to the news consumers. Ophir, (2018) further argues that provision of little details from organization mandated to do so, break the public chain of information hence affecting their decision making in preparedness to deal with current outbreaks. The SARS outbreak in 2003 brought a significant concern by the global media on its role in reducing its high mortality rate as well as the rapid spread to 29 nations within weeks. Scholars (Lee et al., 2019; Pieri, 2019) concluded that the SARS was poorly handled, leading to the Hong Kong government's reputation being put at stake (Lee et al., 2019; Pieri, 2019). The failure claimed during this situation included the infectiveness of the government in providing concrete prevention and containment. At the same time, the media complained about the lack of transparency of the government on the issue at hand.

\section{NEWS FRAMES IN COMMUNICATING CORONAVIRUS OUTBREAKS}

Neuman et al. (1992) explained four types of news frames that are used in framing news stories. These are; economic consequence, human impact, moral and conflict frames. In utilizing the human impact context, Valkenburg et al. (1999) deconstructed it further by adding the elements of responsibility and human interest as components on news framing. In this study, we have reconstructed and borrowed the frames from both Neuman and Valkenburg that are deemed relevant in exploring the media coverage of the initial stages of the COVID-19 pandemic.

\section{Economic Consequences}

During a crisis, major businesses and investments are always economically affected. The effect might be both positive in the way some business generating revenues while others suffer losses. The financial impact is what is referred to as the economic framing (Iyengar, 1990). The economic and political dimensions of the crises get momentum when the epidemic progresses. Travel advisory by governments affects the economic sphere of specific ventures. Although the lift of the ban of the travel advisory allows for the minute economic coverage, the focus is pinned to the health story. Stakeholders are focused on this stage to reassure and also to offer expert advice that is deemed vital in the situation.

\section{Human Interest and Impact Frame}

In the case of outbreaks, the media has continued to offer human interest stories that relate to the epidemics (Iyengar, 1990). These kinds of stories include people who are affected, whether directly or indirectly. The use of the human interest frame allows for the integration of the human face (Beaudoin, 2007) or emotional angle into a news story. People who have been affected by a particular epidemic are on the verge of telling the stories which are far believed by news audiences (Beaudoin, 2007; Oh \& Zhou, 2012; Tian \& Stewart, 2005). Therefore, this adds value to the news and elevates the credibility of the press.

\section{Attribution of Responsibility}

Whenever an outbreak erupts, there is always a possibility of it being coined to a particular situation, person, or something that has gone amiss. Therefore, it is essential to figure out the genesis of an epidemic to be able to analyze it critically before its being reported. The communication during the public outbreak improves the understanding of the crisis by adversely reducing uncertainty and reassuring the victims (Iyengar, 1990). Consequently, this limits the amount of criticism towards an epidemic and creates a mutual understanding of resolving the issue. Therefore, it is argued that newsworthy of a story should pass the Ebola standards. The standards are not limited to sensationalism, prominence, as well as emotional appeal. The significance of proximity, the criteria for their attribution, tend to fit the newsworthiness because of their mysterious and their cause of a higher number of fatalities (Iyengar, 1990; Pieri, 2019).

\section{HEALTH SEVERITY FRAME}

Outbreaks have the potential of spreading very fast and reaching a wide area. Their sudden increase in involving several causalities makes them epidemic. Therefore, this affects more than the expected numbers in a given population (Iyengar, 1990; Pieri, 2019). The speedy transmission poses a threat to both the local and international spheres. The media takes a higher chance of reducing the uncertainty of the disease. Management of this information and onward transmission requires a well-coordinated effort (Neuman et al., 1992) from different stakeholders involved. Timely and accurate information minimizes the risk of misinformation (Iyengar, 1990) and hence allows for decision making. A piece of well-calculated information flows during the epidemic is crucial for the improvement of disease prevention and minimization of its spread (Iyengar, 1990; Neuman et al., 1992; Pieri, 2019). 
Table 1. Percentages of tone distribution across the news media organizations

\begin{tabular}{|c|c|c|c|c|}
\hline \multicolumn{5}{|c|}{ Percentage tone distribution across news media } \\
\hline \multicolumn{2}{|c|}{ Newspaper Type } & Optimistic & Pessimistic & Neutral \\
\hline \multirow{2}{*}{$\mathrm{BBC}$} & $\mathrm{N}$ & 5 & 49 & 2 \\
\hline & $\%$ of Total N & $8.9 \%$ & $37.4 \%$ & $4.1 \%$ \\
\hline \multirow{2}{*}{ Al-Jazeera } & $\mathrm{N}$ & 18 & 40 & 8 \\
\hline & $\%$ of Total N & $32.1 \%$ & $30.5 \%$ & $16.3 \%$ \\
\hline \multirow{2}{*}{ People’s Daily } & $\mathrm{N}$ & 20 & 22 & 20 \\
\hline & $\%$ of Total N & $35.7 \%$ & $16.8 \%$ & $40.8 \%$ \\
\hline \multirow{2}{*}{ CNN } & $\mathrm{N}$ & 13 & 20 & 19 \\
\hline & $\%$ of Total N & $23.2 \%$ & $15.3 \%$ & $38.8 \%$ \\
\hline \multirow{2}{*}{ Total } & $\mathrm{N}$ & 56 & 131 & 49 \\
\hline & $\%$ of Total N & $100.0 \%$ & $100.0 \%$ & $100.0 \%$ \\
\hline
\end{tabular}

\section{RESEARCH QUESTIONS}

The following research questions guided the study.

RQ1. How did BBC, Al-Jazeera, CNN, and People's Daily tone the current COVID-19?

RQ2. What were the major frames of these four media in their reporting regarding COVID-19?

RQ3. What themes emerged from BBC, Al-Jazeera, CNN, and People's Daily, respectively, in the reporting of COVID-19?

\section{METHODOLOGY}

The study adopted a pragmatic approach and utilized content analysis as a method. As argued by Bryman (2012), content analysis is a research method that is best placed to study news contents delivering the results of both qualitative and quantitative methods. In analyzing the news stories, the study borrowed micro framing analysis from (Entman, 1993 and Iyengar, 1991). This was relevant in examining how perceptions about the disease outbreak were made by the news media organizations based on the information that they presented to their audiences. This is in agreement with Scheufele \& Tewksbury (2007, p. 12), who further posits that the micro-level construct of framing elaborates how people use the information that they have received to create impressions on issues and events, thus significantly contributing to the public's perceptions.

Wimmer and Dominick (2006) recommend the use of framing analysis reinforced by content analysis in the analysis of news stories. Therefore, this study examined the language used, the content presentation, and the tones reflected in the stories. A code sheet was created to capture all the relevant story information, including; news organization, the publication date, the story heading, the story narrative, the definition of the frames, and the tones.

The initial themes codes of the stories were based on news framing, as suggested by Neuman et al. (1992) and Valkenburg et al. (1999). These were the economic consequence, human interest and impact, attribution of responsibility, and health severity. Each was given a numeric code of 1-4, respectively. The measurement of tones in the news was classified into three categories, namely, optimistic, pessimistic, and neutral. This was similar to a study by (Machungo, 2012) who regarded a news story as optimistic if it covered aspects of the disease outbreak in a hopeful and reassuring way. If the news story was sceptical about any issue of the disease with the potential to make the audience have negative emotions, then it was considered pessimistic. And finally, if it contained both optimistic and pessimist tones in equal measures or if it lacked any risk judgment, then it was considered to be neutral. The tones were numerically coded as 1-3, respectively.

\section{Sampling}

The study employed a consecutive day sampling technique where an every-other-day sample of 15 days per month was used for each media house to achieve a systematic variation of the disease outbreak news content. This was consistent with Riffe et al. (1993) who suggest that a 15-day consecutive day sampling means do not differ significantly from the mean of the population. Random sampling, which accords all the stories an equal chance of being studied, was employed in choosing three stories for each of the consecutive dates selected for the study period, which was from January 1, 2020, to February 29 2020. From the above, a total of 244 COVID-19 news stories comprised the sample and the unit of analysis for the study.

To get the news stories, we searched for the keyword "coronavirus" and "Wuhan pneumonia" in the four international news organization websites (BBC, CNN, Al-Jazeera, and People's daily) from January 1, 2020, to February 29, 2020. The choice of the period sampled was to explore the initial reactions and responses to the outbreak before and one month after the World Health Organization declaration of the disease outbreak as a global emergency on January 31, 2020. The qualitative content was thematically analyzed. Both the researchers read and independently coded all the stories using the coding schema from Ethman, which consisted of four major categories. The discrepancies that arose were discussed until a consensus was arrived at. Descriptive statistics were used in analyzing the frames and tones across the media houses.

\section{RESULTS}

The findings of this study are categorized into six themes from the four media, which reported the COVID-19 to answer the research questions. It is interesting to note that other frames like stereotype and conspiracy theories, emerged and therefore, it is prudent to be reported as findings of this study. Based on the sampling criteria above, a total of 59 news stories from BBC, 63 news stories from Al-Jazeera, 54 from $\mathrm{CNN}$, and 67 from People's Daily were reported with the focus of the COVID-19 pandemic since January 1 to February 29, 2020. 
Table 2. Percentages of theme distribution across the news media organizations

\begin{tabular}{|c|c|c|c|c|c|}
\hline \multicolumn{6}{|c|}{ Percentage frame distribution across news media } \\
\hline \multicolumn{2}{|c|}{ Newspaper Type } & Economic Consequence & $\begin{array}{c}\text { Human Interest and } \\
\text { Impact }\end{array}$ & $\begin{array}{l}\text { Attribution of } \\
\text { Responsibility }\end{array}$ & Health Severity \\
\hline $\mathrm{BBC}$ & $\mathrm{N}$ & 29 & 21 & 41 & 53 \\
\hline \multirow{2}{*}{ Al-Jazeera } & $\mathrm{N}$ & 46 & 12 & 54 & 66 \\
\hline & $\%$ of Total N & $48.9 \%$ & $16.0 \%$ & $28.6 \%$ & $29.9 \%$ \\
\hline \multirow{2}{*}{ People's daily } & $\mathrm{N}$ & 6 & 14 & 56 & 52 \\
\hline & $\%$ of Total N & $6.4 \%$ & $18.7 \%$ & $29.6 \%$ & $23.5 \%$ \\
\hline \multirow{2}{*}{ CNN } & $\mathrm{N}$ & 13 & 28 & 38 & 50 \\
\hline & $\%$ of Total N & $13.8 \%$ & $37.3 \%$ & $20.1 \%$ & $22.6 \%$ \\
\hline \multirow{2}{*}{ Total } & $\mathrm{N}$ & 94 & 75 & 189 & 221 \\
\hline & $\%$ of Total N & $100.0 \%$ & $100.0 \%$ & $100.0 \%$ & $100.0 \%$ \\
\hline
\end{tabular}

RQ1. How did BBC, Al-Jazeera, CNN, and People's Daily Tone the COVID-19 Pandemic?

The coverage of the COVID-19 pandemic in its initial stage, which represented the first two months between January 1, 2020, and February 29, 2020, is depicted in Table 1. Out of the four news organizations, $\mathrm{BBC}$ had most of their news stories being pessimistic, while People's Daily coverage being more neutral and also optimistic. CNN coverage of COVID-19 had the least number of pessimistic stories across the four media houses.

RQ2. What were the Major Frames of these Four Media in their Reporting of the COVID-19 Pandemic?

The representation of the distribution of news frames across the news media organizations is represented in Table 2. A key observation in the study was that most of the stories from the news organizations included multiple news frames. Under the economic consequence frame, Al-Jazeera had the most news stories. In contrast, CNN had more stories with the human interest and impact news frames, and People's Daily had more stories than the other media houses depicting the attribution of responsibility news frames.

RQ3. What Themes Emerged from BBC, Al-Jazeera, CNN, and People's Daily, Respectively, in the Reporting of COVID-19?

\section{Sinophobia}

Sinophobia came up as a prominent theme that was widely covered by the three out of the four media while reporting the COVID-19 pandemic. This was not only stipulated in the economic consequences frame, but it also emerged in the areas of the attribution and responsible news frames. In the story covered by the BBC, Sinophobia surfaced. The people who aim to spread the disease to the rest of the world. The Asian minorities are physically shunned in public places and tagged as a 'virus' hence being the target of racism.

"In the weeks since the virus spread around the world, multiple accounts of discrimination against Chinese nationals or anyone who looks East Asian have emerged, including from Asia and Chinese-majority societies. [...] Asian minorities and Chinese nationals say virus-related racism and xenophobia have thrived. [...]in places where Asians are a visible minority such as Europe, the US, and Australia, the Sinophobia appears to be fueled by superficial stereotypes of the Chinese as dirty and uncivilized" (BBC, February 7, 2020).

On the other hand, $\mathrm{CNN}$ also reported on how Asian minorities are a target of xenophobic attacks during the spread of COVID-19 pandemic. In this is news CNN emphasized on the cease of discriminating against the Chinese and people of Asian origin.

\begin{abstract}
"Canadian Prime Minister Justin Trudeau is cautioning against discrimination toward the Asian community over the coronavirus outbreak. Trudeau urged Canadians to stay united and warned against the rise of prejudice as fears of the novel virus spread. News of the virus has led to reports of a reemergence of racism and xenophobia against Asian people in Canada" (CNN, February 18, 2020).
\end{abstract}

The People's Daily published a comprehensive article on what it figured to be a xenophobic story about the Asian people during the COVID-19 pandemic outbreak. The story was meant to seek clarification regarding the Wall Street Journal Publication on which it was termed as an insult to Chinese nationals.

"A racially discriminatory article published by the Wall Street Journal has recently triggered a battle against xenophobia and discrimination amid China's ongoing efforts to fight against the virus. [...] The offensive op-ed has also caused a public uproar in China, with China's Ministry of Foreign Affairs demanding an apology from WSJ on several occasions" (People's Daily, Feb, 24, 2020).

\section{Crime related}

All three out of four media reported crime story that related to the COVID-19 pandemic. Some of these stories ranged from a protest on the way the COVID-19 was mishandled. To the hoarding of goods that are essential in the current epidemic.

"Ukraine's effort to quarantine more than 70 people evacuated from China over the new virus outbreak has plunged into chaos, as residents opposing the move hurled stones at the evacuees and clashed with police.[...] Demonstrators, some of whom appeared drunk, put up roadblocks, burned tires and clashed with riot police who moved to clear access. One protester tried to ram police lines in his car. Nine police officers and one civilian were hospitalized, the regional police said in a statement. Ukrainian police said 24 protesters were detained" (BBC, February 21, 2020).

Al-Jazeera, on the other hand, covered the following story in regards to the crime during COVID-19 spread in china. The story targeted individuals who alleged to put roadblocks that hindered the flow of people during the outbreak. 
"People who set up check posts without approval or break up roads to stop traffic - along with other acts designed to disrupt the flow of vehicles amid the ongoing epidemic will face prosecution, the Ministry of Public Security said" (Al-Jazeera, Jan, 28,2020).

Besides, the People's Daily covered the crime story involving individuals who commit the crime by assaulting, injuring, or intentionally killing medical workers.

"Seven crimes relating to medical workers during the prevention and control of novel coronavirus-caused pneumonia outbreak will be strictly combated following a document on Saturday.[...]offenders should be harshly fought during the epidemic period, such as those who assault, intentionally kill or intentionally injure medical workers, or people who restrict the personal freedom of medical staff members using threat or violence" (People's Daily, February 8 , 2020).

\section{Misinformation and fake news}

In the wake of the COVID-19, all the four media covered the story concerning either fake news, conspiracy theories, or misinformation. For instance, the BBC included the following;

"But not only has the virus spread, so too has misinformation. Numerous conspiracies have appeared since the outbreak - not to mention dubious health advice. Journalists and fact-checkers have found posts with identical or slightly altered wording said to be from local health authorities - are also being circulated on Facebook and WhatsApp in Canada, Pakistan and India" (BBC, January 30, 2020).

CNN covered the story of the heroic doctor who succumbed to death by the virus. The doctor had indicated to the public about the virus. But it was regarded as rumours by the authorities in China.

"Li Wenliang, 34, was a Wuhan doctor who was widely hailed as a hero after it emerged, he was targeted by police for spreading "rumours" about the virus when he was sharing accurate information to try and raise the alarm" (CNN February 7, 2020).

Al-Jazeera reported the following story in regards to misinformation and rumours or fake news during the outbreak of the COVID-19.

"Rumourmongering and slanderous attacks will be cracked down on following the law, and rumours or fake news about the epidemic situation will be dealt with promptly, the ministry said” (Al-Jazeera, February 5, 2020).

\section{Geopolitics and international relations}

Geopolitics took centre stage during the reporting of the COVID19 pandemic by CNN and BBC media. This came due to concerns about different economic consequences and developing a scenario of countering the spread of the disease.

"The economic shocks from the virus [...] and the prolonged shutdown of many factories and businesses across China [...] are being felt worldwide, with ramifications for the global oil industry and automakers.[...]Hong Kong, in particular, is feeling the pain from the virus outbreak. The semiautonomous Chinese city was already in a technical recession due to the US-China trade war and over six months of protests, and a massive drop in tourists and business due to the outbreak has further pushed down the economy" (CNN, February 6 , 2020).

On reporting about COVID-19, the BBC focused on geopolitics among Russia, China, and the UNITED STATES. This speculated both the conspiracy theories and misinformation about the origin and the spread of the virus.

"The coronavirus outbreak in China has provided fertile ground for conspiracy theories and misinformation on the web everywhere, but in Russia, they are spread on primetime news programs. Russian TV is also unique in having a consistent overall thrust: that shadowy Western elites and especially the US are somehow ultimately to blame [...] The aim is variously said to be - in the case of "Big Pharma" - to profit from creating a vaccine against the coronavirus or, in the case of the US, to hit the Chinese economy to weaken a geopolitical competitor" (BBC, February 7, 2020).

\section{DISCUSSIONS}

From the results above, our study reflects the international news media's response to the COVID-19 pandemic at its initial stages. Several Scholars have investigated the news media framing of disease outbreaks using different frames. S. T. Lee, (2014) applied Iyengar's (1991) thematic and episodic frames in investigating the framing of infectious diseases while Harris (2016) examined the different stages of a crisis, from the pre-crisis phase, the crisis stage and the post-crisis stage. In this study, we went beyond Entman and Iyengar's news media framing. We reconstructed the news frames from both Neuman (1992), and Valkenburg et al. (1999) then came up with four frames earlier discussed to analyze the media coverage of COVID-19.

\section{News Frames and Themes}

Sinophobia, crime, geopolitics, international relations, misinformation and fake news, are the emergent themes that defined the perspectives from which the news media originations viewed the pandemic. The frame also reflected the progressive spread of the disease, especially to the countries where the news media are located.

In the first month of January, the study observed that BBC, CNN, and Al-Jazeera news media coverage depicted the pandemic as a Chinese problem. Consequently, this led to stigmatization and Sinophobia on the Chinese by people from other countries for fear of infection. This was similar to the observations made by McCauley et al. (2013) during the H1NI Flu outbreak in 2009-2010, where the news media coverage was deemed to have played a part in activating fears that Latinos and Mexicans were responsible for the spread of the disease. A similar observation made by Govender (2017) observed that media framing of Ebola virus as an African problem. It played a part fuelling xenophobia as exemplified by several US schools and colleges that turned African students away for fear of contracting the Ebola virus. 
Despite the students not having been to Africa or even coming from African countries that did not have the virus.

In this study, news stories from the BBC, CNN, People's Daily, and Al-Jazeera pegged the Wuhan Seafood market in China as the origin of the disease. Consequently, people started blaming the Chinese as being responsible for the COVID-19 disease. This led to reported incidents of Sino-phobia, stereotypes, and stigmatization of the Chinese people living outside China, especially in countries where they are a minority. McCauley, Minsky, and Viswanath (2013) observed that during periods of uncertainty, global health emergencies could be regarded as social stressors. These social stressors can act as stimuli that trigger latent fears that some people have about people from other ethnic or racial groups, consequently resulting in cases of stigmatization or discrimination.

Additionally, with China under lockdown and people working from home, it meant that most factories were closed in containing the outbreak. This took a toll on the international stock markets with prices plummeting. However, Brahmbhatt and Dutta (2008), when analyzing the economic effects during SARS, noted that the media coverage of a pandemic, if not correctly done, can result in the public overreacting during pandemics. The news media in public health emergencies can, at times, through their rapid 24 hours news coverage of the pandemic, cause people to make subjective assessments of the pandemic facts and lead to panic, which may result in costly economic mistakes made in attempting to protect themselves and their loved ones.

This has been observed in this study as well, with news reports of people doing excessive shopping of face masks, hand sanitizers, and household products in an attempt to prevent infections. This is also consistent with the 2016 report by the National Academy of Medicine on Countering Infectious Disease Crises, where they noted that access to media reports tends to triggers fears among people resulting in changes in their behaviour patterns as they try to avoid getting infected. The concern is created by both ignorance and awareness from technology and media. This was observed in the case of SARS which according to WHO, had a mortality rate of 8,000 people (WHO, 2003) but registered estimated Economic costs of more than $\$ 40$ billion in Hong Kong, with retail sales dropping by 50\% (Siu and Wong, 2004), and the air traffic reduced by $80 \%$ (Lee \& McKibbin, 2003).

Additionally, the declaration of the COVID-19 as a Global public health emergency on January 30, 2020, due to the perceived risks of the disease to other countries, made it a global health security issue, with several countries taking measures to protect their citizens. This took a toll on the international relations between China and the global world. One of the critical international diplomacy strategies of the Chinese government has been the going out strategy through initiatives such as the Belt and Road Initiative and also through Forum on China-Africa Cooperation (FOCAC).

These international relations were tested during the initial stage of the disease outbreak, with most of the countries evacuating their citizens. A move initially, the Chinese were hesitant to recommend. However, most African nations chose to show their solidarity with the Chinese people by not evacuating their citizens and also as exemplified by the national carrier for Ethiopia who declined to cancel their flights to China despite the call from other countries to do so. Additionally, health systems in Africa still at infancy stages were also cited as reasons why most African governments preferred to let their citizens stay in China. This reaction to pandemics as global security concerns was also observed during the Ebola virus in 2014, where Pieri (2019) notes that the UK media is quoting the then US president Barrack Obama advanced the narrative of Ebola Virus as a global security threat.

Mason and Giahyue (2014) also argued that the media reframing the Ebola virus as a global security threat extended its reach beyond its point of origin, fuelling fears of countries being crippled and economies breaking down. This same narrative is being replicated in the coverage of COVID-19, with some countries deploying military personnel at the airports to facilitate screenings of people coming in.

\section{Tones of the News Stories}

In our study, we observed that the People's Daily, which is assumed to reflect the Chinese government position, also had some pessimistic stories at $16.8 \%$ in comparison to the other news media organizations. Most of these pessimistic stories were in response to refute some of the media coverage of the pandemic from the different international media perspectives. This is reflected in their criticism of being accused of mishandling the outbreak in its initial stages. The government banning some western journalists from reporting in China on the coronavirus, and the increased reported cases of Sinophobia against the Chinese in some western countries. These it seems might have made the news organization adapt to a western journalistic style of being critical in defence of Chinese government decisions in the handling of the COVID-19 pandemic and also in responding to the treatment meted on the Chinese people in the western countries.

The use of alarmist tones was also very prevalent in the study with words such as "deadly disease," "scary," and "high fatality rate" being commonly used by the news media organizations. The use of such tones is similar to an observation made by Yu, Frohlich, and Ren. (2011) in analyzing newspaper coverage of H1N1 in the United States, where they observed that words like "fatal," "deadly," "huge death toll," and lethal were used by 5.3 per cent of the sample news articles. The use of alarmist tones in news coverage was also observed by Vasterman and Ruigrok (2013) in their study analyzing Dutch Media coverage of H1N1, where they noted that $74 \%$ of the media messages had alarmist tones in the reportage.

Celine, Enny, and Hartmann (2016) further posit that the use of different tones by news media organizations in their media framing could be attributed to the differences among the different countries. Especially on concerning exposure to the disease, the news cultures in a specific country which might differ across different regions and the media systems as well. These differences were exemplified in the study as the disease outbreak spread to other countries. The international news media organizations toned down the pessimistic and othering of the disease to China and the Chinese people. The media houses then started being more neutral in their coverage, with February observing more appeals on cautionary measures, the political leaders calling for cooperation in dealing with the pandemic and the news media reliance on the WHO for directions. Moreover, some government personalities contracting the disease, and self-isolating has led to most governments implementing stricter control in containing the situation by closing borders and in an attempt to protect their citizens. The media houses were more optimistic and advocating against misinformation and the spread of fake news and are constantly advising their news consumers to seek clarification from WHO. 


\section{CONCLUSION}

In conclusion, this study offers valuable insights into the media framing and tones used by news media organizations in the coverage of the COVID-19 pandemic at its initial stages as well as identifying the different themes that are embedded in reporting this kind of pandemic. The media play an essential role in providing information at the initial stages of a disease outbreak. Its function is crucial in influencing the public perceptions of the disease and also contribute to curbing the spread of the epidemic. The results indicate that more needs to be done to stop the repetition of themes and narratives that relate to discrimination and stigmatization of those infected or affected by disease outbreaks.

\section{REFERENCES}

Assiri, A., McGeer, A., Perl, T. M., Price, C. S., Al Rabeeah, A. A., Cummings, D. A. T., Alabdullatif, Z. N., Assad, M., Almulhim, A., Makhdoom, H., Madani, H., Alhakeem, R., Al-Tawfiq, J. A., Cotten, M., Watson, S. J., Kellam, P., Zumla, A. I., \& Memish, Z. A. (2013). Hospital outbreak of middle east respiratory syndrome coronavirus. New England Journal of Medicine, 369(5), 407-416. https://doi.org/10.1056/NEJMoa1306742

Beaudoin, C. E. (2007). SARS News Coverage and Its Determinants in China and the US. International Communication Gazette, 69(6), 509524. https://doi.org/10.1177/1748048507082839

Brahmbhatt, M., \& Dutta, A. (2008). On SARS Type Economic Effects During Infectious Disease Outbreaks (January 2008). World Bank Policy Research Working Paper 4466. https://doi.org/10.1596/ 1813-9450-4466

Bryman, A. (2012). Social Research Methods. New York: Oxford University Press.

CDC. (2020). First travel-related case of 2019 novel coronavirus detected in the United States. 21 January 2020. Retrieved on 26 January 2020 from https://www.cdc.gov/media/releases/2020/ p0121-novel-coronavirus-travel-case.html

Celine, K., Enny, D., \& Tilo, H. (2016). Swine flu and hype: a systematic review of media dramatization of the H1N1 influenza pandemic, Journal of Risk Research, 19(1), 1-20. https://doi.org/10.1080/ 13669877.2014.923029

Entman, R. M. (1993). Framing: Towards clarification of a fractured paradigm. Journal of Communication, 43(4), 51-58. https://doi.org/10.1111/j.1460-2466.1993.tb01304.x

Gislason, M. K. (2013). West Nile virus: the production of a public health pandemic. Sociological Health Illness, 35(2), 188-199. https://doi.org/10.1111/j.1467-9566.2012.01535.x

Govender, S. (2017). Mistakes, Muddles, and Mixed Messages: How disjointed health reporting is confusing the issues and costing lives. Retrieved on 19 March 2020 from https://reutersinstitute. politics.ox.ac.uk/our-research/mistakes-muddles-and-mixedmessages-how-disjointed-health-reporting-confusing-issues

Harris, P. (2016). Achoo! Three Major US Newspapers Reporting on the Flu Before and After H1N1 (Masters Thesis). Retrieved from http://commons.lib.jmu.edu/master201019/91
Huang, C., Wang, Y., Li, X., Ren, L., Zhao, J., Hu, Y., ... Cao, B. (2020). Clinical features of patients infected with 2019 novel coronavirus in Wuhan, China. The Lancet, S0140673620301835. https://doi.org/10.1016/S0140-6736(20)30183-5

Idoiaga-Mondragon, N., Gil-de-Montes, L., \& Valencia, J. (2017). Understanding an Ebola outbreak: social representations of emerging infectious diseases. Journal. Health Psychology, 22(7), 951960. https://doi.org/10.1177/1359105315620294

Iyengar, S. (1990). Framing responsibility for political issues: The case of poverty. Political Behavior, 12(1), 19-40. https://doi.org/ 10.1007/BF00992330

Iyengar, S. (1991). Is anyone responsible? How television frames political issues. Chicago: University of Chicago Press. https://doi.org/ 10.7208/chicago/9780226388533.001.0001

Lee, J., \& McKibbin, W. (2003). Globalization and Disease: The Case of SARS. Working Paper No. 2003/16, Research School of Pacific and Asian Studies, Australian National University and the Brookings Institution, Washington, DC.

Lee, M., Ju, Y., \& You, M. (2019). The Effects of Social Determinants on Public Health Emergency Preparedness Mediated by Health Communication: The 2015 MERS Outbreak in South Korea. Health Communication, 1-11. https://doi.org/10.1080/10410236.2019. 1636342

Lee, S. T. (2014). Predictors of H1N1 Influenza Pandemic News Coverage: Explicating the Relationships between Framing and News Release Selection. International Journal of Strategic Communication, 8(4), 294-310. https://doi.org/10.1080/1553118X. 2014.913596

Machungo, F. G. (2012). Trends and Content of Media Coverage of the HIV/Aids Epidemic in Africa By Three Influential US Newspapers, 19832008. 216.

Mason, J., \& Giahyue, H. (2014). Citing security threat, Obama expands the US role fighting Ebola. Reuters, September 16. Retrieved on 19 March 2020 from https://www.reuters.com/article/us-healthebola-Obama/citing-security-threat-obama-expands-u-s-rolefighting-ebola-idUSKBNOHB08S20140916

McCauley, M., Minsky, S., \& Viswanath, K. (2013). The H1N1 pandemic: Media frames, stigmatization and coping. BMC Public Health, 13(1), 1116. https://doi.org/10.1186/1471-2458-13-1116

Neuman, W. R., Just, M. R., \& Crigler, A. A. (1992). Common KnowledgeNews and Construction of Political Meaning. The University of Chicago Press. https://doi.org/10.7208/chicago/9780226161174. 001.0001

Oh, D. C., \& Zhou, W. (2012). Framing sars: A case study in toronto of a mainstream newspaper and a chinese ethnic newspaper. Atlantic Journal of Communication, 20(5), 261-273. https://doi.org/10.1080/15456870.2012.728113

Ophir, Y. (2018). Spreading News: The Coverage of Epidemics by American Newspapers and Its Effects on Audiences-A Crisis Communication Approach. 203.

Pieri, E. (2019). Media framing and the threat of global pandemics: The ebola crisis in uk media and policy response. Sociological Research Online, 24(1), 73-92. https://doi.org/10.1177/1360780418811966 
Riffe, D., Aust, C. F., \& Lacy, S. R. (1993). The effectiveness of random, consecutive day and constructed week sampling in newspaper content analysis. Journalism \& Mass Communication Quarterly, 70(1), 133-139. https://doi.org/10.1177/107769909307000115

Scheufele, D. A., \& Tewksbury, D. (2007). Framing, agenda-setting, and priming: The evolution of three media effects models. Journal of Communication, 57(1), 9-20. https://doi.org/10.1111/j.00219916.2007.00326.x

Seto, W., Tsang, D., Yung, R., Ching, T., Ng, T., Ho, M., Ho, L., \& Peiris, J. (2003). Effectiveness of precautions against droplets and contact in prevention of nosocomial transmission of severe acute respiratory syndrome (Sars). The Lancet, 361(9368), 1519-1520. https://doi.org/10.1016/S0140-6736(03)13168-6

Siu, A., \& Wong, R. Y. C. (2004). Economic Impact of SARS: The Case of Hong Kong. Asian Economic Papers, 3(1), 62-83. https://doi.org/10.1162/1535351041747996

Tian, Y., \& Stewart, C. M. (2005). Framing the sars crisis: A computerassisted text analysis of cnn and bbc online news reports of sars. Asian Journal of Communication, 15(3), 289-301. https://doi.org/10.1080/01292980500261605
Valkenburg, P. M., Semetko, H. A., \& De Vreese, C. H. (1999). The effects of news frames on readers' thoughts and recall. Communication Research, 26(5), 550-569. https://doi.org/10.1177/009365099026005002

Wallis, P., \& Nerlich, B. (2005). Disease metaphors in new epidemics: the UK media framing of the 2003 SARS epidemic. Sociological Science Medicine, 60(11), 2629-2639. https://doi.org/10.1016/ j.socscimed.2004.11.031

WHO (2020). Novel coronavirus - China January 12, 2020. Retrieved on 26 January 2020 from http://www.who.int/csr/don/12january-2020-novel-coronavirus-china/en/

World Health Organization. (2003). Consensus document on the epidemiology of severe acute respiratory syndrome (SARS) (No. WHO/CDS/CSR/GAR/2003.11). World Health Organization.

Wimmer, R. D., \& Dominick, J. R. (2006). Mass media research, An introduction. Wadsworth Publishing: Belmont.

Yu, N., Frohlich, D. O., Fougner, J., \& Ren, L. (2011). Communicating a Health Epidemic: A Risk Assessment of the Swine Flu Coverage in US Newspapers. International Public Health Journal 3(1, Special Issue on "Health Risk Communication"), 63-76. 